explore changes in global fire regimes during a period of high millennial-scale climate variability. Biomass burning at the global scale apparently responded rapidly to variations in temperature, as recorded in the Greenland ice core. Increases in biomass burning were synchronous with warming, whereas cooling was accompanied by decreases in burning followed by a return of fire to previous levels. Changes in vegetation productivity and fuel availability may explain the inferred variations in biomass burning during D-O cycles.

Additional paleofire records are still needed to derive statistically robust results at a regional scale and to better examine fire and climate interactions. Global biomass burning responds to past temperature variations, but we also seek to explore the importance of seasonality of temperature and precipitation on fire, which play a role in shaping the vegeta- tion (type of biomes, abundance of fuel) and the flammability of fuel. We intend to extend the database by adding worldwide long and high-resolution marine and terrestrial charcoal records, in particular from poorly documented areas of North America, Africa and Eurasia. There is a great potential for long marine records to document regional fire activity where terrestrial records are not available. Characterization of the role of temperature and precipitation on fire would also benefit from the close comparison between fire and well-documented high-resolution changes in vegetation during $\mathrm{D}-\mathrm{O}$ climate shifts, for example, in Europe where these rapid changes led to an alternation between open and forested biomes.

\section{Data}

The data presented herein will be available in the version 2 of the Global Charcoal Database when it is released (see http://www.gpwg.org/).

\section{Acknowledgements}

I thank P.J. Bartlein, M.F. Sánchez-Goñi, W. Tinner and C. Whitlock for helpful comments and English revision, which greatly improved the manuscript.

\section{References}

Daniau, A.-L., Harrison, S.P. and Bartlein, P.J., in press: Fire regimes during the Last Glacial, Quaternary Science Reviews, doi:10.1016/j. quascirev.2009.11.008.

Marlon, J.R., et al., 2009. Wildfire responses to abrupt climate change in North America, Proceedings of the National Academy of Sciences, 106(8): 2519-2524 doi: 10.1073/ pnas.0808212106.

Power, M.J., Marlon, J.R., Bartlein, P.J. and Harrison, S.P., 2010: Fire History and the Global Charcoal Database: a new tool for hypothesis testing and data exploration, Palaeogeography, Palaeoclimatology, Palaeoecology, 291(1-2): 52-59.

Sánchez-Goñi, M.F. and Harrison, S.P., in press: Millennial-scale climate variability and vegetation changes during the last glacial: concepts and terminology, Quaternary Science Reviews, doi:10.1016/j.quascirev.2009.11.014

Wolff, E.W., Chappellaz, J., Blunier, T., Rasmussen, S.0. and Svensson, A., in press: Millennial-scale variability during the last glacial: The ice core record, Quaternary Science Reviews, doi:10.1016/j. quascirev.2009.10.013

\title{
A fire paradox in ecosystems around the Mediterranean
}

\author{
Boris VAnNière ${ }^{1}$, D. Colombaroli ${ }^{2}$ and N. Roberts ${ }^{3}$ \\ ${ }^{1}$ CNRS, Chrono-Environment Laboratory, University of Franche-Comté, Besançon, France; boris.vanniere@univ-fcomte.fr \\ Institute of Plant Sciences and Oeschger Center for Climate Change Research, University of Bern, Switzerland; ${ }^{3}$ School of Geography, Earth and \\ Environmental Sciences, University of Plymouth, UK
}

\section{Multi-proxy sedimentary charcoal records show that, despite evidence of early human-induced fire, the regional-scale switch from climate-regulated to human-dominated biomass burning occurred only between 4 and $2 \mathrm{ka}$ in the Mediterranean region, coinciding with a late-Holocene expansion of fire-adapted ecosystems.}

Wildfires in Mediterranean countries are a regular agent of disturbance for ecosystems and are generally attributed to a combination of extreme summer drought, strong winds and heat-waves along with accidental-or sometimes deliberateignition by human hands (e.g., Pausas, 2004). While these factors are certainly among the contemporary causes, the ultimate causes operating over multi-decadal and longer timescales are far from fully understood. What does the past tell us about the respective roles of climate and human actions in determining long-term Mediterranean fire regimes? Compared with other Mediterranean-like ecosystems in the world (e.g., chaparral in California), the Mediterranean basin has experienced a long history of human occupation, with human fire use recorded as far back as 0.8 Ma in eastern Mediterranean regions (Alperson-Afil, 2008). The spread of agriculture in the Mediterranean started more than $11 \mathrm{ka}$ ago and Neolithic populations were present in the whole region from $\mathrm{ca} .7 \mathrm{cal}$ ka BP (Bocquet-Appel et al., 2009). Thus, disentangling climate and human causes is often difficult in the Mediterranean area because these drivers may operate syner- gistically. Well-dated sedimentary archives help us to understand when fire regimes switched from being climate- to humandominated across the region. In recent years, multi-proxy studies and regional- to global-reconstructions of biomass burning have greatly improved our knowledge about fire-climate-human interactions in the past. Here we discuss how Holocene fire-ecosystem-climate-human linkages can be inferred from paleoecological studies in the Mediterranean area.

\section{Fire-vegetation-climate relationships}

Recent charcoal-based studies from welldated lake sediments show that fire frequency in the Mediterranean region varied significantly throughout the last 11.6 ka (Holocene). Fire has played a contrasting role in the history of circum-Mediterranean landscape ecosystems; sometimes positive (e.g., increasing biodiversity) and at other times negatively affecting ecosystems (e.g., disrupting forest stands; Vannière et al., 2008). For instance, paleoecological records show that late-summer grassland burning delayed the early postglacial re-advance of woodland across in- terior areas of southwest Asia by up to $3 \mathrm{ka}$ (Turner et al., 2010). In Sicily (Gorgo Basso; Fig. 1A), higher fire frequency before $8 \mathrm{cal}$ ka BP probably restricted broadleaved evergreen stands (Tinner et al., 2009). Similarly, and in contrast to commonly held ecological assumptions, high-resolution pollen and charcoal time series from different sites in the central Mediterranean show that evergreen forest ecosystems (e.g., with Quercus ilex) were disadvantaged or even irretrievably destroyed by fire (Colombaroli et al., 2009; Fig. 1B). Thus, increasing drought and/or fire activity in the future could strongly endanger relict stands of $Q$. ilex in southern parts of the Mediterranean region and favor the expansion of drought-adapted maquis vegetation.

Multi-proxy approaches have provided additional insights. For example, Turner et al. (2008) compared proxies for fire activity (microscopic charcoal data, particles $<180 \mu \mathrm{m}$ in diameter), land use and vegetation (pollen data) and climate (oxygen isotope data) from Eski Acıgöl crater record (Central Turkey; Fig. 2A). Landscape burning coincided with periods of wetter climate at centennial- to millennial- 
timescales, implying that wildfires were fuel-limited in this oak-grass parkland ecosystem. Only in the late Holocene did climate and fire activity become decoupled in terms of timing. These data imply that, for most of the Holocene, wet-dry oscillations in climate acted as the pacemaker for biomass burning intensity, and that the switch from a climate- to a human-regulated fire regime took place only during the last 2 to 3 millennia.

A high-resolution sedimentary charcoal record from Lago dell'Accesa (Tuscany, Italy) reveals a mean Holocene fire interval of ca. 150 years, which is very close to present values of quasi-natural fire frequency in Mediterranean ecosys- tem, according to historical and modern ecological studies (Vannière et al., 2008). High-resolution pollen data from Lago dell'Accesa show that the area around the lake was occupied by Neolithic settlements ca. 8 ka, and that fire was the primary tool used to create open environments for agricultural and grazing purposes (Colombaroli et al., 2008). Nonetheless, longterm trends in fire return intervals compared with reconstructed lake-level trends (Magny et al., 2007; Vannière et al., 2008; Fig. 2B) suggest that, for the major part of the record, the amplitude and rhythms of hydrological and fire frequencies followed the same trend. Specifically, high fire frequency periods were triggered by drier
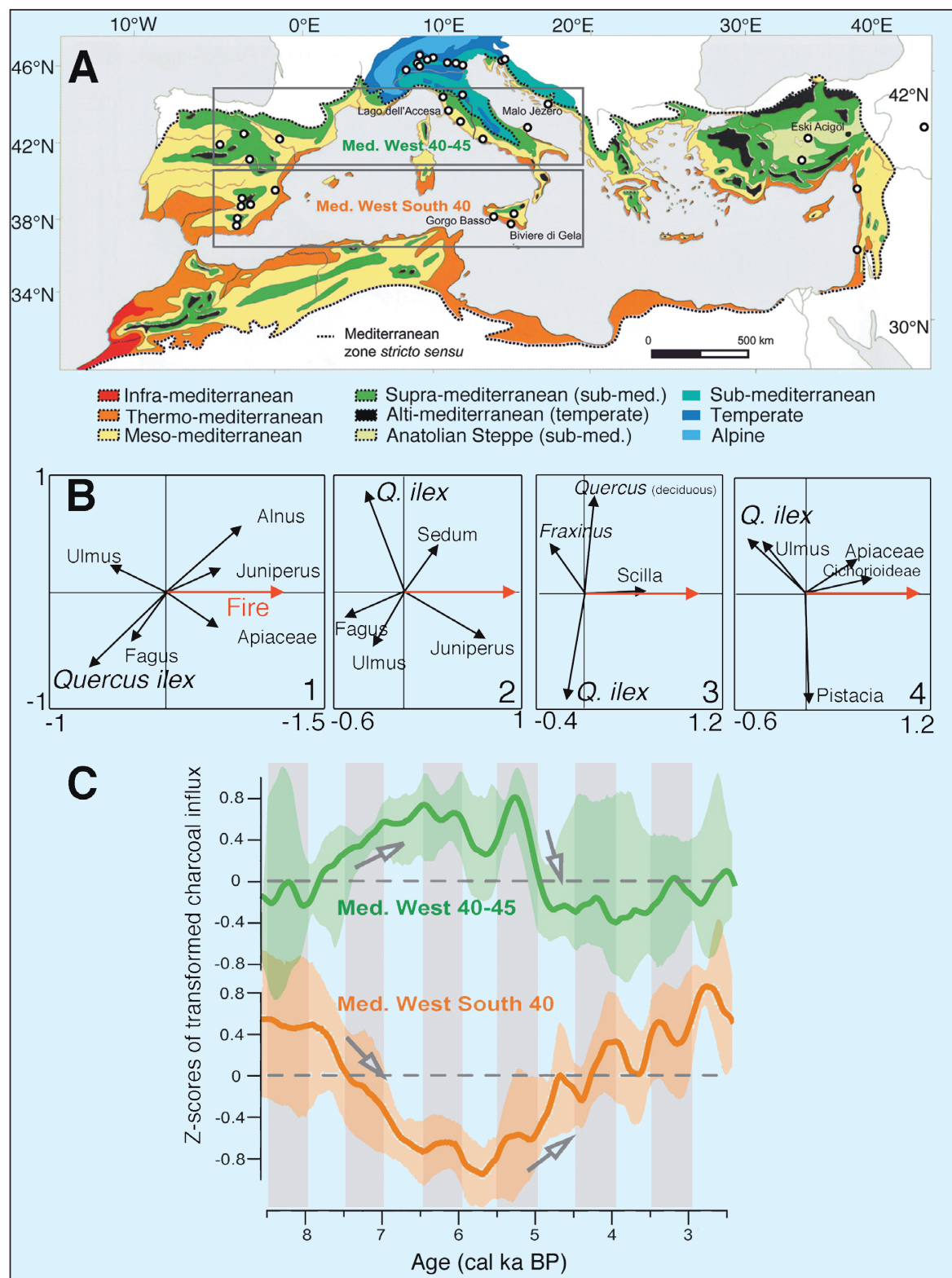

Figure 1: A) Mediterranean bioclimates (modified from Ozenda and Borel, 2000; Quézel and Médail, 2003) and the limit of the Mediterranean zone stricto sensu (Quézel and Médail, 2003). White circles mark the location of charcoal records of the Mediterranean fire synthesis by Vannière et al. (in press) and cited in this paper. The two boxes delimit the groups of sites used in panel $C ; \boldsymbol{B})$ Redundancy analysis biplot showing species response to fire at four Mediterranean sites: 1) Lago di Massaciuccoli (Tuscany, Italy) 2) Malo Jezero (Croatia) 3) Lago dell'Accesa (Tuscany, Italy) 4) Biviere di Gela (Sicily, Italy). Arrow direction indicates the association among species and the environmental variable (fire); arrows pointing in the same direction indicate a positive correlation (modified from Colombaroli et al., 2009); C) Regional Z-scores of transformed charcoal influx (particles $\mathrm{cm}^{-2} \mathrm{a}^{-1}$ ) from the western Mediterranean (250-a smoothing window/1000-a bootstrap): averaging sites between 40-45 N ("Med. West 40-45") and sites south of $40^{\circ} \mathrm{N}$ ("Med. West South 40") (modified from Vannière et al., in press). Envelopes represent the upper and lower confidence intervals from the bootstrap analysis. Dashed lines correspond to the mean values of the base period: 21 to 0.02 cal ka BP. climatic conditions and especially a dry summer season that promoted ignition and biomass burning. From ca. 4 cal ka BP the signals became decoupled, which is likely related to interferences with human activities. Demographic increase coupled with changing agricultural practices strongly modified vegetation cover (fuel), and fire frequency was enhanced by deliberate burning for woodland clearance and fields/pasture management.

\section{Regional fire synthesis}

Many examples highlight site-specific fire responses to climate change depending on fuel availability and indicate a switch from climate- to human-regulated burning regimes between 4 and 2 cal ka BP. To what extent is this also evident in aggregated multi-site syntheses?

Analysis of regional fire activity based on 36 sedimentary charcoal records by Vannière et al. (in press; Fig. 1A) shows spatial coherency within, but differences between, areas of the Mediterranean. During the mid-Holocene Thermal Maximum (approx. 9-5 ka BP), charcoal records from the northern Mediterranean suggest the region was fire prone, while records from the southern Mediterranean indicate a decrease in fire activity from early Holocene levels, closely associated with wetterthan-present summers. In the central and western Mediterranean, there is a northsouth partition around $40-43^{\circ} \mathrm{N}$. Relatively rapid changes in fire regime at ca. $5.5-5 \mathrm{cal}$ ka BP may have been tied to a weakening of Asian and African monsoon strength, which indirectly influences Mediterranean climate mechanisms and results from the orbitally induced summer cooling trend (Tinner et al., 2009; Vannière et al., in press). These records attest to important changes in seasonal climate around the Mediterranean during the Holocene, in contrast to previous notions of gradual aridification of the entire region or a series of short-term events occurring in a chaotic manner across space and time (Beaulieu et al., 2005; Sadori et al., 2008; Jalut et al., 2009; Fig. 1C). Although fire activity decreased after 5.5-5 cal ka BP in northern Mediterranean regions, the southern part of the Mediterranean generally experienced increased fire activity associated with drier summer conditions. During the late Holocene, starting from 4-3.5 cal ka $\mathrm{BP}$, paleoecological evidence shows that fire-tolerant Mediterranean ecosystems expanded together with large-scale landuse conversion by Bronze Age and later cultures, and this permanently changed biomass availability and burning activity 
A) Eski Acıgöl Lake (Turkey)

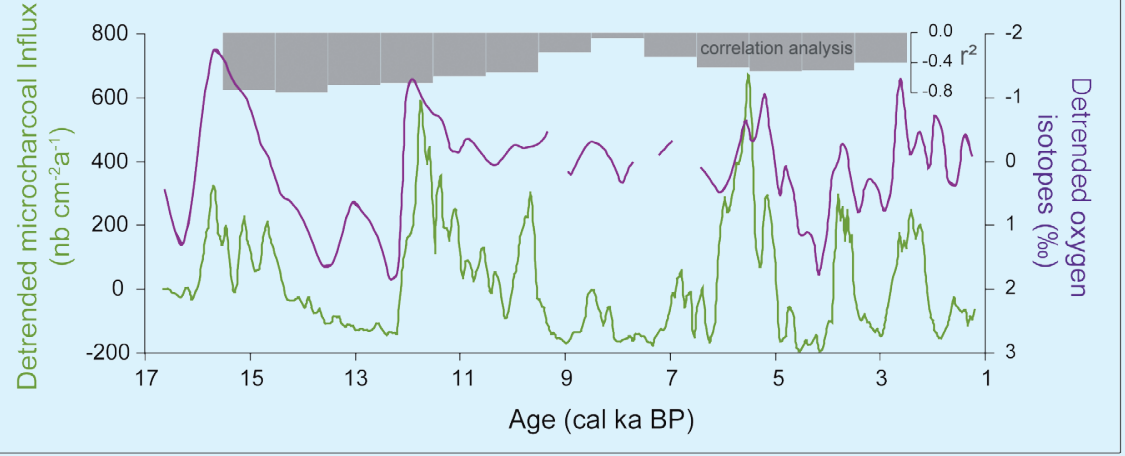

B) Lago dell'Accesa (Italy)

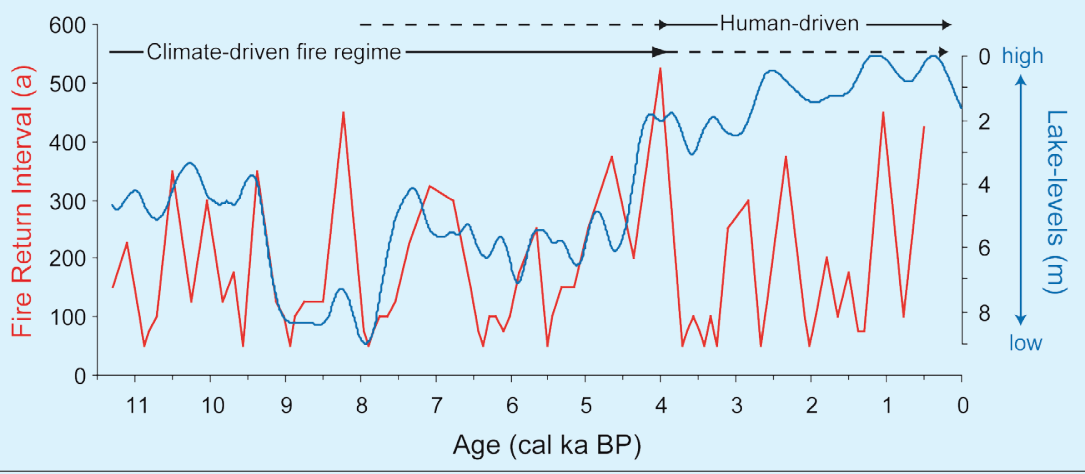

Figure 2: $\boldsymbol{A}$ ) Detrended microscopic charcoal (green line) and oxygen isotope record (purple line) for Eski Acıöl Lake (Turkey). Correlation analysis (gray bars) shows statistically significant correlations between microscopic charcoal influx (particles $\mathrm{cm}^{-2} \mathrm{a}^{-1}$ ) and $\delta^{18} \mathrm{O}(\%)$ for most of the record (modified from Turner et al., 2008); B) Lago dell'Accesa (Tuscany, Italy) lake-level fluctuations (blue line; modified from Magny et al., 2007) and the fire-return interval (red line) reconstructed from fire-event detection based on sedimentary macroscopic charcoal (modified from Vannière et al., 2008). Peaks in the fire-return interval curve correspond with high lake-level stands before 4 cal ka BP. across the Mediterranean (Carrión et al., 2003, 2007; Sadori et al., 2008).

\section{Conclusion}

The paleofire record from the Mediterranean is paradoxical. Climatic variations have certainly acted as one of the main pacemakers of fire regimes, particularly in the first half of the Holocene. Under different climate conditions (e.g., seasonality of precipitation), the southern and northern Mediterranean may have been terranean Europe. Even apparently wellestablished relationships, such as evergreen oaks being favored by fire, turn out to be wrong when viewed over decadal to centennial timescales. These complex long-term responses are significant in the context of increasing aridity and warming, as well as major regional land-use changes linked to agricultural and tourism development around the Mediterranean Sea. Understanding them will help us to better manage and preserve one of the most fireprone regions of the world, characterized by extraordinary plant diversity.

\section{Data}

The data are submitted to the Global Palaeofire Working Group Database (http://www.gpwg. org) and are available by contacting B. Vannière (boris.vanniere@univ-fcomte.fr)

\section{Acknowledgements}

We are greatly indebted to M. Magny, M. Power, W. Tinner and R. Turner who have contributed to these results and for enriching discussions about paleofire. Many thanks also to all contributors to the Mediterranean part of the Global Charcoal Database.

\section{References}

Colombaroli, D., Tinner, W., van Leeuwen, J.F.N., Noti, R., Vescovi, E., Vannière, B., Magny, M., Schmidt, R. and Bugmann, H., 2009: Response of broad-leaved evergreen Mediterranean forest vegetation to fire disturbance during the Holocene: insights from the peri-Adriatic region, Journal of Biogeography, 36: 314-326.

Colombaroli, D., Vannière, B., Chapron, E., Magny, M. and Tinner, W. 2008: Fire-vegetation interactions during the Mesolithic-Neolithic transition at Lago dell'Accesa, Tuscany, Italy, The Holocene, 18: 679-692.

Turner, R., Roberts, N. and Jones, M.D., 2008: Climatic pacing of Mediterranean fire histories from lake sedimentary microcharcoal, Global and Planetary Change, 63: 317-324.

Vannière, B., et al., in press: Circum-Mediterranean fire activity and climate changes during the mid Holocene environmental transition (8500-2500 cal yr BP), The Holocene.

Vannière, B., Colombaroli, D., Chapron, E., Leroux, A., Tinner, W. and Magny, M., 2008: Climate versus human-driven fire regimes in Mediterranean landscapes: the Holocene record of Lago dell'Accesa (Tuscany, Italy), Quaternary Science Reviews, 27: 1181-1196.

\title{
Tropical fire ecology across the African continent: A paleoecological perspective
}

\author{
Daniele Colombaroli ${ }^{1,2}$ and Dirk Verschuren ${ }^{2}$ \\ 'Institute of Plant Sciences and Oeschger Center for Climate Change Research, University of Bern, Switzerland; daniele.colombaroli@ips.unibe.ch \\ 'Limnology Unit, Department of Biology, Ghent University, Belgium
}

\section{High-resolution charcoal records from African lake sediments provide new insights for longstanding research questions on fire-climate-human interactions in tropical and subtropical ecosystems.}

Every year, the tropics experience more fire than any other region in the world (Fig. 1). Tropical grassland (savannah) fires are the dominant source of carbon from biomass burning and provide more than $60 \%$ of the global total (Mouillot and Field, 2005). However, much of what is known about tropical fire ecology is based on monitoring programs started within the last decade, with highly fragmentary historical data extending only to the early $20^{\text {th }}$ century. These data do not allow us to assess whether recent trends in fire frequency and magnitude are unusual in the context of natural long-term ecosystem dynamics (Gillson and Willis, 2004).

\section{Natural or anthropogenic fire regime?}

Seventy percent of tropical and subtropical areas worldwide are considered to have ecologically degraded fire regimes (Shlisky et al., 2007). In Africa, the recent increase in fire frequency is attributed to human ecosystem disturbance associated 